\title{
Affinity of naloxone and its quaternary analogue for avian central $\delta$ and $\mu$ opioid receptors
}

\author{
Pierre Deviche * \\ Institute of Arctic Biology, University of Alaska Fairbanks, Fairbanks, AK 99775-7000, USA
}

Accepted 25 February 1997

\begin{abstract}
Quaternary narcotic antagonists that are assumed not to penetrate the blood-brain barrier following systemic administration are commonly used to distinguish between peripheral and central actions of opiates. In mammals, these antagonists have a lower affinity for opioid receptors than their tertiary parent compounds. The relative affinity of quaternary vs. tertiary antagonists either for opioid receptors in non-mammalian species or for specific receptor subtypes has, however, not been determined. Using brain tissues from a passerine songbird (Junco hyemalis), we found the affinity of the quaternary antagonist, naloxone methiodide (Nal MI), for brain opioid receptors to be less than $10 \%$ that of $\mathrm{Nal} \mathrm{HCl}$. Further, Nal MI affinity for $\mu$ and $\delta$ receptors is $8.7 \%$ and $3.7 \%$, respectively, that of $\mathrm{Nal} \mathrm{HCl}$. These results confirm that tertiary narcotic antagonist quaternization substantially reduces the affinity of these derivatives for central opioid receptors. They show that this reduction is receptor-type selective, and they extend previous reports demonstrating functional similarities between mammalian and non-mammalian central opioid receptors.
\end{abstract}

Keywords: Naloxone; Quaternary naloxone; Opioid; Mu receptor; Delta receptor; Junco; DAMGO; DPDPE

Treatment with opioid receptor antagonists such as naloxone ( $\mathrm{Nal}$ ) and naltrexone ( $\mathrm{Ntx}) \mathrm{HCl}$ is widely used to assess the involvement of opioid systems in physiological and behavioral functions. Nal readily enters the brain when given peripherally [30]. Studies involving the systemic administration of opioid antagonists such as $\mathrm{Nal}$ and $\mathrm{Ntx}$ do, therefore, not identify whether the effects are peripherally or centrally mediated since these effects may result from changes in opioid receptor occupancy within, but also outside, the central nervous system.

Quaternary opioid antagonist derivatives such as Nal methobromide and methiodide (MI) are designed to not penetrate the blood-brain barrier as easily as their tertiary counterparts [22]. Comparing the influence of quaternary vs. tertiary narcotic antagonists given systemically should, thus, permit the differentiation between peripherally vs. centrally mediated opioid receptor blockade effects. This approach has, however, several limitations [2]. Specifically, there is evidence that quaternary opioid antagonists

\footnotetext{
* Corresponding author. Fax: + 1 (907) 474-6967; e-mail: ffpjd1@aurora.alaska.edu
}

(or their biologically active metabolites) can, indeed, enter the central nervous system when administered systemically [29,31]. Additionally, in vivo and in vitro studies found that opioid antagonist affinity for peripheral and central receptors is considerably reduced following their quaternization [2]. For example, the ability of methylnaloxone to compete for rat brain $\left[{ }^{3} \mathrm{H}\right]$ etorphine binding sites in vitro is less than $10 \%$ that of $\mathrm{Nal} \mathrm{HCl}$ [2]. As a result, studies involving the administration of tertiary and corresponding quaternary opioid antagonists at a single (e.g., equimolar) dose are generally difficult to interpret.

Brain tissues contain three well-characterized opioid receptor types $(\delta, \mu$, and $\kappa)[7,33,34]$ and $\mathrm{Nal}, \mathrm{Ntx}$ and etorphine non-selectively bind to all receptor types $[11,18]$. At the present time, the relative affinity of tertiary vs. corresponding quaternary antagonists for each receptor type has not been measured. Information on this subject is of direct relevance for the interpretation of studies on the physiological and behavioral effects of opioid antagonist treatment, because some opioid-mediated functions primarily involve a specific receptor type [19,25,26]. To address this question, the present study compares the relative affinities of $\mathrm{Nal} \mathrm{HCl}$ and $\mathrm{MI}$ for brain $\delta$ and $\mu$ opioid receptors by determining the potency of these drugs to 
compete in vitro either for $\left[\mathrm{Tyr}-3,5-{ }^{3} \mathrm{H}\right]\left[\mathrm{D}-\mathrm{Pen}^{2}, \mathrm{pCl}-\right.$ $\left.\mathrm{Phe}^{4}, \mathrm{D}-\mathrm{Pen}{ }^{5}\right]$ enkephalin $\left(\left[{ }^{3} \mathrm{H}\right] \mathrm{pCl}\right.$-DPDPE, a $\delta$ receptorselective agonist [32]) or for $\left[\mathrm{Tyr}-3,5-{ }^{3} \mathrm{H}(N)\right]\left[\mathrm{D}-\mathrm{Ala}^{2}, N\right.$ Me-Phe ${ }^{4}$, Gly-ol $\left.{ }^{5}\right]$ enkephalin $\left(\left[{ }^{3} \mathrm{H}\right] \mathrm{DAMGO}\right.$, a $\mu$ receptor-selective agonist $[10,15])$ binding sites.

Previous research identified central opioid receptor subtypes in non-mammalian vertebrates (birds: [5,27]; fish: [8]), but little information is available on whether these receptors are equivalent to those of mammals functionally. This issue was examined by using an avian species (Darkeyed Junco, Junco hyemalis) as the experimental model. This species is appropriate because its brain tissues contain specific high-affinity $\delta, \mu$ and $\kappa$ binding sites that are differentially located anatomically $[6,12]$ and have general pharmacological properties resembling those of mammalian receptors [6].

Tissue collection and preparation. Juvenile Dark-eyed Juncos (1 male; 2 females) were collected from a local population in September and held in captivity under short photoperiod until mid-May, at which time they had reached adulthood. Birds were sacrificed by decapitation, and their brains (not including the spinal cord) were removed and frozen by immersion into Freon, then stored at $-70^{\circ} \mathrm{C}$ for 4 days, at which time they were processed. No decrease in opioid binding activity was detected in brains that were stored for at least 1 year in identical conditions (Deviche and Gulledge, unpublished).

Brains were thawed and homogenized on ice using a glass pestle and homogenizer. Homogenates were pooled, transferred to a $12 \times 75 \mathrm{~mm}$ plastic tube, and frozen in Freon. Frozen sections (thickness: $30 \mu \mathrm{m}$ ) were collected onto serially numbered gelatin-coated microscope slides (3 sections/slide). They were dehydrated overnight at $4^{\circ} \mathrm{C}$ under partial vacuum and stored at $-70^{\circ} \mathrm{C}$ in air-tight boxes until used. In previous studies, individual sections contained 150-300 $\mu \mathrm{g}$ proteins (depending on the homogenate) as measured by the Lowry's et al. technique [6,17], and sections prepared from a same homogenate contained consistent amounts of proteins (e.g., $n=8 \mathrm{sec}-$ tions: $304 \pm 25 \mu \mathrm{g}$ protein/section; coefficient of variation: $8.2 \%)$.

Competition curves. Sections were incubated as previously described [6]. Briefly, they were thawed and pre-incubated for $30 \mathrm{~min}$ at room temperature in buffer containing $150 \mathrm{mM} \mathrm{NaCl}$ to dissociate endogenous ligands. Sections were then rinsed twice in a large volume of buffer and incubated in sodium-free buffer $(600 \mu \mathrm{l} / \mathrm{slide})$ containing either $\left[{ }^{3} \mathrm{H}\right] \mathrm{pCl}$-DPDPE $(47.0 \mathrm{Ci} / \mathrm{mmol}$; New England Nuclear, Boston, MA) or $\left[{ }^{3} \mathrm{H}\right]$ DAMGO (48.9 $\mathrm{Ci} / \mathrm{mmol}$; i.d.). To avoid the introduction of artifactual differences between $\mathrm{Nal} \mathrm{HCl}$ and $\mathrm{MI}$ competition curves, all slides to be incubated with a same ligand were processed at the same time. Further, slides were used in a random order, not in the order in which they were filled with sections. Radioligand concentrations in the incubation buffer $\left(\left[{ }^{3} \mathrm{H}\right]\right.$ pCl-DPDPE: $5.2 \mathrm{nM} ;\left[{ }^{3} \mathrm{H}\right]$ DAMGO: $\left.10.8 \mathrm{nM}\right)$ equaled twice their respective equilibrium dissociation constants $\left(K_{\mathrm{d}}\right)$ [6]. The incubation buffer also contained either $\mathrm{Nal} \mathrm{HCl}$ (Endo Laboratories, New York, NY) or Nal MI (Research Biochemicals, Natick, MA) at concentrations ranging between 0 ("total binding") and $50 \mathrm{mM}$. Two slides (i.e., six homogenate sections) were incubated in each condition. After $1 \mathrm{~h}\left(\left[{ }^{3} \mathrm{H}\right] \mathrm{DAMGO}\right)$ or overnight $\left(\left[{ }^{3} \mathrm{H}\right] \mathrm{pCl}\right.$-DPDPE) incubation at room temperature in a humid chamber, slides were repeatedly rinsed in ice-cold buffer [6] and dipped in ice-cold distilled water. Sections were immediately wiped from the slides using Whatman glass fiber filters. Filters were placed into liquid scintillation counting vials, and filter-bound radioactivity was measured in a $\beta$-counter.

Data analysis. Data (d.p.m./section) obtained for sections that were incubated in identical conditions were averaged. Competition curve parameters (non-specific binding, apparent Hill coefficient, and unlabeled competitor concentration inhibiting $50 \%$ of the specific binding $\left(\mathrm{IC}_{50}\right)$ ) were determined using a non-linear curve fitting technique (LIGAND computer program [23]). Apparent Hill coefficients were calculated based only on unlabeled competitor concentrations that inhibited between 5\% and 95\% of the specific binding [20,21]. Equilibrium dissociation constants $\left(K_{\mathrm{i}}\right)$ were calculated using Cheng and Prusoff's equation [3], based on $K_{\mathrm{d}}$ values obtained from equilibrium binding isotherms [6].

At equilibrium, only a small fraction $(\leq 10 \%)$ of the total amount of radioligand available for binding should be specifically bound to the tissue [21]. In the present investigation, $314 \mathrm{fmol} / 600 \mu \mathrm{l}\left[{ }^{3} \mathrm{H}\right] \mathrm{pCl}$-DPDPE or $6.5 \times 10^{3}$ fmol/600 $\mu 1\left[{ }^{3} \mathrm{H}\right]$ DAMGO was initially dispensed onto the slides. At equilibrium, the specific binding accounted for $80 \%\left(\left[{ }^{3} \mathrm{H}\right] \mathrm{pCl}\right.$-DPDPE $)$ and $77 \%\left(\left[{ }^{3} \mathrm{H}\right] \mathrm{DAMGO}\right)$ of the total binding; further, less than $3 \% /$ section of the amount of radioligand present in the incubation medium $\left(\left[{ }^{3} \mathrm{H}\right] \mathrm{pCl}-\right.$ DPDPE: $7.6 \mathrm{fmol}$; $\left[{ }^{3} \mathrm{H}\right]$ DAMGO: $10.02 \mathrm{fmol}$ ) were specifically bound per section.

Competition curves between $\left[{ }^{3} \mathrm{H}\right] \mathrm{pCl}$-DPDPE or $\left[{ }^{3} \mathrm{H}\right] \mathrm{DAMGO}$ and either $\mathrm{Nal} \mathrm{HCl}$ or $\mathrm{Nal} \mathrm{MI}$ are shown on Fig. 1, and binding parameters are presented in Table 1.

$\mathrm{Nal} \mathrm{HCl}$ and $\mathrm{MI}$ both inhibited the specific binding of the radioligands to their receptors in a dose-related manner. Apparent Hill coefficients were in all cases close to unity, suggesting that binding reactions followed mass action principles.

The affinity of Nal MI for $\mu$ opioid receptors is considerably less than that of $\mathrm{Nal} \mathrm{HCl}\left(K_{\mathrm{i}}\right.$ ratio: $10.2 / 117.4 \times$ $100=8.7 \%$ ). Similarly, Nal MI binds to $\delta$ receptors with a much lower affinity than $\mathrm{Nal} \mathrm{HCl}$. In this case, however, the $K_{\mathrm{i}}$ ratio equals only $3.7 \%$. The relative affinity of the two competitors for $\delta$ and $\mu$ receptors, therefore, is opioid receptor type-specific.

The present study determined in vitro parameters of $\mathrm{Nal}$ $\mathrm{HCl}$ and $\mathrm{MI}$ binding to avian brains by incubating slidemounted whole tissue homogenate sections in the presence 
of labeled ligands, then removing sections from the slides, and finally measuring tissue-bound radioactivity by liquid scintillation. Compared with in vitro receptor autoradiography, this technique has the advantage of eliminating potential errors that are associated with measuring relative optical densities from films and with extrapolating receptor densities from the values of calibrated standards. It has been used to successfully characterize opioid receptors in nervous tissues of juncos [6] as well as of mammals $[9,14,16,24]$.

The results demonstrate that $\mathrm{Nal} \mathrm{HCl}$ binds with a high affinity to junco brain opioid receptors, as it does in another bird species (chick, Gallus domesticus [1,4]). Junco brain $\mathrm{Nal} \mathrm{HCl}$ affinity constants for $\delta$ and $\mu$ receptors are generally similar to those reported in mammalian investigations $[13,28,32]$. With previous studies characterizing opiate agonist binding to junco brain tissues [6], these observations support the idea that avian and mammalian brain opioid receptors have similar properties with regards to opioid antagonist binding.

Numerous parameters are likely to modulate the behavioral and/or physiological effects of $\mathrm{Nal} \mathrm{HCl}$ and $\mathrm{MI}$ given systemically. These include the distribution of these drugs in various body components, the ease at which they cross the blood-brain barrier, their metabolism, and their degradation rates. The interpretation of studies comparing the influence of these antagonists after peripheral administration also requires knowledge of their relative affinities

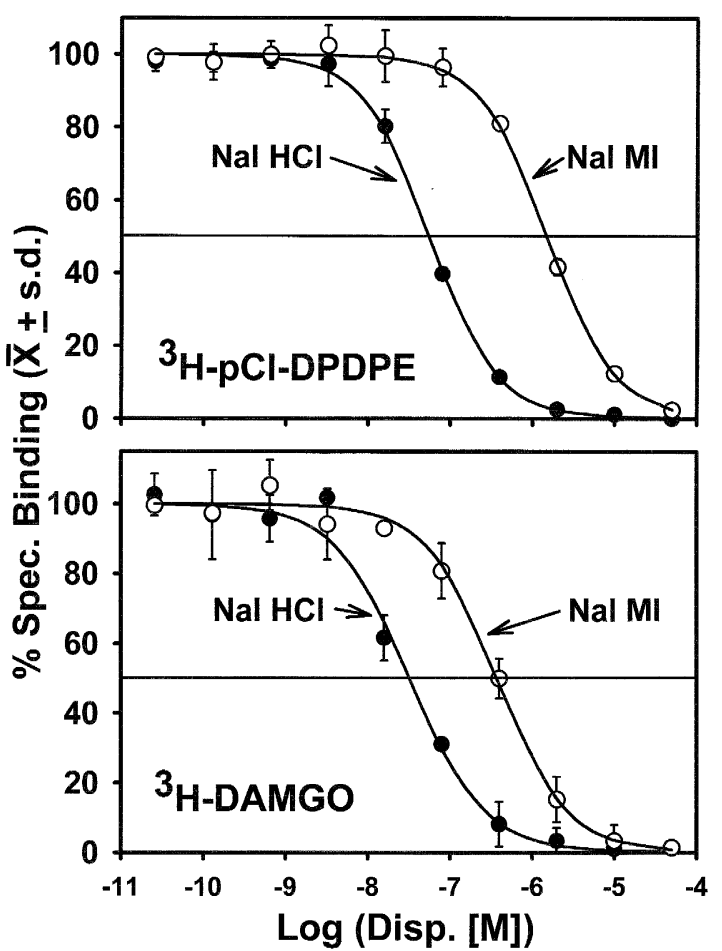

Fig. 1. Dose-related inhibition of the specific binding of $\left[{ }^{3} \mathrm{H}\right] \mathrm{pCl}-\mathrm{DPDPE}$ and $\left[{ }^{3} \mathrm{H}\right]$ DAMGO to $\delta$ and $\mu$ brain opioid receptors, respectively, by naloxone ( $\mathrm{Nal}) \mathrm{HCl}$ or its quaternary derivative, Nal methiodide (MI). Each point represents the mean $( \pm$ S.D.) of six values. Note that some S.D. values are contained within the corresponding symbol.
Table 1

Characteristics of the inhibition of $\left[{ }^{3} \mathrm{H}\right] \mathrm{pCl}$-DPDPE and $\left[{ }^{3} \mathrm{H}\right]$ DAMGO binding to brain opioid receptors by naloxone methiodide

\begin{tabular}{|c|c|c|c|}
\hline \multirow[t]{2}{*}{ Labeled ligand } & \multicolumn{2}{|l|}{ Competitor } & \multirow[t]{2}{*}{ Ratio $(2 / 1)$} \\
\hline & $\mathrm{Nal} \mathrm{HCl}(1)$ & Nal Ml (2) & \\
\hline \multicolumn{4}{|l|}{$\left[{ }^{3} \mathrm{H}\right] p C l-D P D P E$} \\
\hline App. Hill coefficient & -1.08 & -1.10 & \\
\hline $1 \mathrm{C}_{50}($ mean \pm S.E.; $\mathrm{nM})$ & $55.9 \pm 3.6$ & $1.5 \times 10^{3} \pm 0.1 \times 10^{3}$ & \\
\hline$K_{\mathrm{i}}(\mathrm{nM})$ & 17.7 & 476.7 & 26.9 \\
\hline \multicolumn{4}{|l|}{$\left[{ }^{3} \mathrm{H}\right] D A M G O$} \\
\hline App. Hill coefficient & -0.91 & -0.72 & \\
\hline $1 \mathrm{C}_{50}($ mean \pm S.E.; nM $)$ & $32.5 \pm 6.9$ & $373.2 \pm 54.3$ & \\
\hline$K_{\mathrm{i}}(\mathrm{nM})$ & 10.2 & 117.4 & 11.5 \\
\hline
\end{tabular}

for opioid receptors. Previous investigations found quaternary opioid antagonists to have a considerably less in vivo and in vitro potency than their parent compounds. Similarly, Nal MI exhibited a markedly lower (over 90\%) affinity than $\mathrm{Nal} \mathrm{HCl}$ for junco central opioid receptors. In other studies, the relative in vitro potencies of quaternary and tertiary opiate antagonists were generally determined by performing competition studies between these drugs and ligands that non-selectively bind to several opioid receptor types $\left(\left[{ }^{3} \mathrm{H}\right]\right.$ etorphine [2]). As a result, potential affinity differences between quaternary and tertiary compounds for $\delta, \mu$ or $\kappa$ opioid receptors separately were not identified. The present report shows the affinity of Nal MI for $\delta$ and $\mu$ receptors to be $3.7 \%$ and $8.7 \%$ (a $2.5 \times$ ratio), respectively, that of $\mathrm{Nal} \mathrm{HCl}$. Thus, differences in affinity between $\mathrm{Nal} \mathrm{MI}$ and $\mathrm{Nal} \mathrm{HCl}$ are receptor typespecific.

Since naloxone quaternarization markedly decreases the affinity of the resulting compound for central opioid receptors, the design of experiments comparing the effects of the two drugs after systemic administration should take this difference into account. Specifically, such experiments should include dose-responses to the two compounds over a wide range of concentrations. Further, the decrease in affinity for central opioid receptors of naloxone MI compared to its tertiary parent compound is larger for $\delta$ than for $\mu$ opioid receptors. Thus, quaternary naloxone may be of little use for studying mechanisms involving central $\delta$ in addition to $\mu$ opioid receptors. Opioid receptors are widely distributed peripherally as well as centrally. Additional studies examining the relative affinities of tertiary and quaternary naloxone for each opioid receptor type in peripheral tissues are warranted to improve our understanding of the behavioral and physiological effects resulting from the peripheral administration of these compounds.

\section{Acknowledgements}

The author thanks D. Eckman for technical assistance and C.G. Gulledge for comments on an early draft of the manuscript. 


\section{References}

[1] M.T. Bardo, R.K. Bhatnagar, G.F. Gebhart, R.A. Hughes, Opiate receptor development in midbrain and forebrain of posthatch chicks, Dev. Brain Res. 3 (1982) 668-673.

[2] D.R. Brown, L.I. Goldberg, The use of quaternary narcotic antagonists in opiate research, Neuropharmacology 24 (1985) 181-191.

[3] Y.C. Cheng, W.H. Prusoff, Relationship between the inhibition constant $\left(\mathrm{K}_{\mathrm{i}}\right)$ and the concentration of inhibitor which causes $50 \%$ inhibition $\left(\mathrm{IC}_{50}\right)$ of an enzymatic reaction, Biochem. Pharmacol. 22 (1973) 3099-3108.

[4] A. Csillag, R.C. Bourne, M. Kalman, M.I. Boxer, M.G. Stewart, $\left[{ }^{3} \mathrm{H}\right]$ Naloxone binding in the brain of the domestic chick (Gallus domesticus) determined by in vitro quantitative autoradiography, Brain Res. 479 (1989) 391-396.

[5] A. Csillag, R.C. Bourne, M.G. Stewart, Distribution of mu, delta, and kappa opioid receptor binding sites in the brain of the one-dayold domestic chick (Gallus domesticus): an in vitro quantitative autoradiography study, J. Comp. Neurol. 302 (1990) 543-551.

[6] P. Deviche, P. Cotter, C.C. Gulledge, Identification, partial characterization, and hypothalamic distribution of kappa, mu, and delta opioid receptors in a passerine songbird (Junco hyemalis), Brain Res. 614 (1993) 220-226.

[7] I.G. Dougall, A critical review of the classification of opioid receptors, Biotechnol. Appl. Biochem. 10 (1988) 488-499.

[8] L.O.E. Ebbesson, P. Deviche, S.O.E. Ebbesson, Distribution and changes in $\mu$-and $\kappa$-opiate receptors during the midlife neurodevelopmental period of Coho salmon, Oncorhynchus kisutch, J. Comp. Neurol. 364 (1996) 448-464.

[9] S.M. Edley, L. Hall, M. Herkenham, C.B. Pert, Evolution of striatal opiate receptors, Brain Res. 249 (1982) 184-188.

[10] M.G.C. Gillan, H.W. Kosterlitz, Spectrum of the mu-, delta- and kappa-binding sites in homogenates of rat brain, $\mathrm{Br}$. J. Pharmacol. 77 (1982) 461-469.

[11] A. Goldstein, A. Naidu, Multiple opioid receptors: ligand selectivity profiles and binding site signatures, Mol. Pharmacol. 36 (1989) 265-272.

[12] C.C. Gulledge, P. Deviche, Autoradiographic localization of opioid receptors in vocal control regions of a male passerine bird (Junco hyemalis), J. Comp. Neurol. 356 (1995) 408-417.

[13] W. Jacobson, M. Wilkinson, Opiate $\left(\left[{ }^{3} \mathrm{H}\right]\right.$ naloxone) binding to hypothalamic and cerebral cortical slices of mouse brain, Brain Res. Bull. 13 (1984) 481-485.

[14] C. Jomary, J.E. Gairin, J. Cros, J.-C. Meunier, Autoradiographic localization of supraspinal $\kappa$-opioid receptors with $\left[{ }^{125} \mathrm{I}_{-} \mathrm{Tyr}{ }^{1}, \mathrm{D}\right.$ Pro ${ }^{10}$ ]dynorphin A-(1-11), Proc. Natl. Acad. Sci. (USA) 85 (1988) 627-631.

[15] H.W. Kosterlitz, S.J. Paterson, Tyr-D-Ala-Gly-MePhe-Gly-ol is a selective ligand for the mu-opiate binding site, Br. J. Pharmacol. 73 (1981) 299.

[16] L.-Y. Liu-Chen, S. Li, M.E. Lewis, Autoradiographic study of irreversible binding of $\left[{ }^{3} \mathrm{H}\right] \beta$-funaltrexamine to opioid receptors in the rat forebrain: comparison with $\mu$ and $\delta$ receptor distribution, Brain Res. 544 (1991) 235-242.

[17] O.H. Lowry, N.J. Rosebrough, A.L. Farr, R.J. Randall, Protein measurement with the Folin phenol reagent, J. Biol. Chem. 193 (1951) 265-275.
[18] J. Magnan, J. Lemay, M. Tiberi, Binding of the non-selective opioid $\left[{ }^{3} \mathrm{H}\right]$ etorphine in the human fetal central nervous system, Dev. Brain Res. 38 (1988) 300-303.

[19] P.E. Mann, C.H. Kinsley, R.S. Bridges, Opioid receptor subtype involvement in maternal behavior in lactating rats, Neuroendocrinology 53 (1991) 487-492.

[20] P. McGonigle, P.B. Molinoff, Receptors and signal transduction: classification and quantification, in: G.J. Siegel et al. (Eds.), Basic Neurochemistry: Molecular, Cellular, and Medical Aspects, 5th Edn., Raven Press, New York, 1994, pp. 209-230.

[21] G.A. McPherson, Kinetic, EBDA, LIGAND, Lowry: a Collection of Radioligand Binding Analysis Programs, Elsevier, Amsterdam, 1985, $127 \mathrm{pp}$.

[22] R.J. Milne, J.M. Coddington, G.D. Gamble, Quaternary naloxone blocks morphine analgesia in spinal but not intact rats, Neurosci. Lett. 114 (1990) 259-264.

[23] P.J. Munson, D. Rodbard, LIGAND: a versatile computerized approach for characterization of ligand-binding systems, Anal. Biochem. 107 (1980) 220-239.

[24] N.L. Ostrowski, T.R. Burke Jr., K.C. Rice, A. Pert, C.B. Pert, The pattern of $\left[{ }^{3} \mathrm{H}\right]$ cyclofoxy retention in rat brain after in vivo injection corresponds to the in vitro opiate receptor distribution, Brain Res. 402 (1987) 275-286

[25] G.W. Pasternak, Pharmacological mechanisms of opioid analgesics, Clin. Neuropharmacol. 16 (1993) 1-18.

[26] J.G. Pfaus, N. Pendleton, B.B. Gorzalka, Dual effect of morphiceptin on lordosis behavior: possible mediation by different opioid receptor subtypes, Pharmacol. Biochem. Behav. 24 (1986) 14611464.

[27] A. Reiner, S.E. Brauth, C.A. Kitt, R. Quirion, Distribution of mu, delta, and kappa opiate receptor types in the forebrain of pigeons, $J$. Comp. Neurol. 280 (1989) 359-382.

[28] D.S. Roane, M.J. Iadarola, J.R. Porter, Decreased $\left[{ }^{3} \mathrm{H}\right]$ naloxone binding and elevated dynorphin-A(1-8) content in Zucker rat brain, Physiol. Behav. 43 (1988) 371-374.

[29] K.G. Smith, D.C. Andersen, Food, predation, and reproductive ecology of the dark-eyed junco in Northern Utah, Auk 99 (1982) $650-661$

[30] F.S. Tepperman, M. Hirst, P. Smith, Brain and serum levels of naloxone following peripheral administration, Life Sci. 33 (1983) 1091-1096.

[31] R.J. Valentino, J.I. Katz, F. Medzihradsky, J.H. Woods, Receptor binding antagonist, and withdrawal precipitating properties of opiate antagonists, Life Sci. 32 (1983) 2887-2896.

[32] L.K. Vaughn, R.J. Knapp, G. Toth, Y.-P. Wan, V.J. Hruby, H.I. Yamamura, A high affinity, highly selective ligand for the delta opioid receptor: $\left[{ }^{3} \mathrm{H}\right]\left[\mathrm{D}-\mathrm{Pen}^{2}\right.$,pCl-Phe $\left.{ }^{4}, \mathrm{D}-\mathrm{Pen}^{5}\right]$ enkephalin, Life Sci. 45 (1989) 1001-1008.

[33] P.L. Wood, Multiple opioid receptors in the central nervous system, in: A.A. Boulton, G.B. Baker, P.D. Hrdina (Eds.), Neuromethods. Vol. 4. Receptor binding, Humana Press, Clifton, NJ, 1986, pp. 329-363.

[34] P.L. Wood, S.E. Charleson, D. Lane, R.L. Hudgin, Multiple opiate receptors: differential binding of mu, kappa and delta agonists, Neuropharmacology 20 (1981) 1215-1220. 